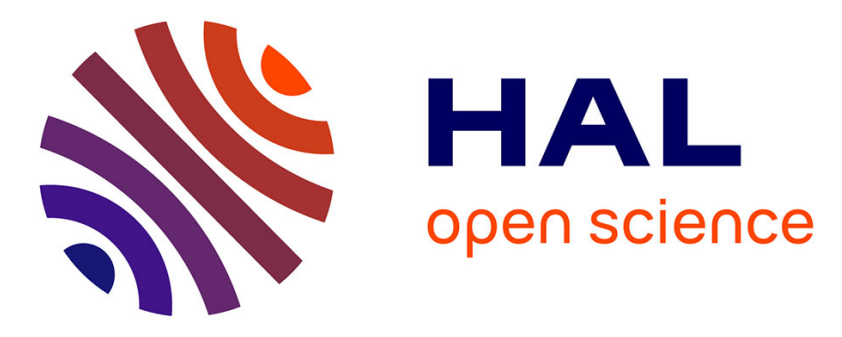

\title{
Light Scattering Measurements with Dust of Interest for IMPF/IMPACT
}

\author{
Edith Hadamcik, Jean-Baptiste Renard, Laifa Boufendi, Guy Cernogora, \\ Anny Chantal Levasseur-Regourd, Cyril Szopa, Marie-Christine Jouanny, V.
}

Leroi

\section{To cite this version:}

Edith Hadamcik, Jean-Baptiste Renard, Laifa Boufendi, Guy Cernogora, Anny Chantal LevasseurRegourd, et al.. Light Scattering Measurements with Dust of Interest for IMPF/IMPACT. 4th International Conference on the Physics of Dusty Plasmas, Jun 2005, Orléans, France. 4 p., 10.1063/1.2134617 . insu-02926333

\section{HAL Id: insu-02926333 \\ https://hal-insu.archives-ouvertes.fr/insu-02926333}

Submitted on 31 Aug 2020

HAL is a multi-disciplinary open access archive for the deposit and dissemination of scientific research documents, whether they are published or not. The documents may come from teaching and research institutions in France or abroad, or from public or private research centers.
L'archive ouverte pluridisciplinaire HAL, est destinée au dépôt et à la diffusion de documents scientifiques de niveau recherche, publiés ou non, émanant des établissements d'enseignement et de recherche français ou étrangers, des laboratoires publics ou privés. 


\title{
Light Scattering Measurements with Dust of Interest for IMPF/IMPACT
}

\author{
Edith Hadamcik ${ }^{1}$, Jean-Baptiste Renard ${ }^{2}$, Laïfa Boufendi ${ }^{3}$, \\ Guy Cernogora ${ }^{1,4}$, Anny-Chantal Levasseur-Regourd ${ }^{1,5}$, \\ Cyril Szopa $^{1,5}$, Marie C. Jouanny ${ }^{3}$, V. Leroi ${ }^{1}$ \\ ${ }^{I}$ Aéronomie/CNRS, BP3, 91371 Verrières, France \\ ${ }^{2}$ LPCE/CNRS, 3A Recherche Scientifique, 45071 Orléans cedex, France \\ ${ }^{3}$ GREMI, 45067 Orléans cedex, France \\ ${ }^{4}$ Univ. Versailles-St Quentin, France, ${ }^{5}$ Univ. Paris VI, 4 place Jussieu, 75005 Paris
}

\begin{abstract}
Light scattering can be used to characterise the physical properties of solid particles (size, refractive index) in dusty plasmas. In the present study, we have collected the dust made in one Argon-silane RF plasma and two Nitrogen-methane RF plasmas. We present polarimetric phase curves of the scattered light obtained ex-situ by the PROGRA ${ }^{2}$ experiment. We propose some interpretations in terms of physical properties of the studied particles.
\end{abstract}

\section{INTRODUCTION}

Numerous measurements have been performed with the PROGRA ${ }^{2}$ experiment (French acronym for Propriétés Optiques des Grains Astronomiques et Atmosphériques) to build a database and to allow the determination of the physical properties (size, morphology) of dust particles of astrophysical and atmospheric interest [1] and to prepare the IMPACT-ICAPS experiment on board the ISS [2]. New series of measurements, including measurements on dust particles produced by RF plasmas are now taking place.

The PROGRA ${ }^{2}$ experiment measures the phase and wavelength dependence of the linear polarization of the light scattered by dust particles. The particles in a vial are lifted either in microgravity conditions (during CNES/ESA airplane campaigns) or by an air-draught in ground-based conditions. The light sources are randomly polarized lasers (red $633 \mathrm{~nm}$ and green $543.5 \mathrm{~nm}$ ). Measurements can be made in a $5^{\circ}-170^{\circ}$ phase range. Two CCD cameras measure the component parallel and perpendicular to the scattering plane [3]. As previously done for other samples [4,5], the goal of this study is to correlate the phase curves parameters with the physical properties of the sample, such as the size and size distribution of the constituent grains, the refractive index and the morphology of the particles. We present here first results for dust lifted by an air-draught. 
TABLE 1. Plasmas conditions for dust production

\begin{tabular}{|c|c|c|c|c|c|}
\hline $\begin{array}{l}\text { Plasmas } \\
\text { Composition }\end{array}$ & Pressure & Temperature & $\begin{array}{l}\text { Absorbed } \\
\text { power }\end{array}$ & Duration & $\begin{array}{l}\text { Particles size } \\
\text { and colour }\end{array}$ \\
\hline $20 \mathrm{sccm} \mathrm{Ar}, 1.8 \mathrm{sccm} \mathrm{SiH} 4$ & & & $10 \mathrm{~W}$ & $\begin{array}{l}30 \text { s pulse } \\
\text { x } 256\end{array}$ & $\begin{array}{l}(90 \pm 20) \mathrm{nm} \\
\text { reddish }\end{array}$ \\
\hline $\begin{array}{l}98 \% \mathrm{~N}_{2}, 2 \% \mathrm{CH}_{4} \\
\text { total } 55 \mathrm{sccm}\end{array}$ & $1 \mathrm{mbar}$ & ambient & $30 \mathrm{~W}$ & continuous & $\begin{array}{l}(720 \pm 200) \mathrm{nm} \\
\text { dark brown }\end{array}$ \\
\hline $\begin{array}{l}90 \% \mathrm{~N}_{2}, 10 \% \mathrm{CH}_{4} \\
\text { total } 55 \mathrm{sccm}\end{array}$ & $1 \mathrm{mbar}$ & ambient & $30 \mathrm{~W}$ & continuous & $\begin{array}{l}(650 \pm 400) \mathrm{nm} \\
\text { pale brown }\end{array}$ \\
\hline
\end{tabular}

\section{SAMPLES}

The samples are dust particles produced by RF capacitely coupled lowpressure plasmas. The first one was produced in an Argon-silane mixture at GREMI. Two Titan's aerosols analogues (tholins) were also produced in Nitrogen-methane mixtures with the PAMPRE experiment at Service d'Aéronomie. The conditions of production are given in table 1 (see also [6], for the description of the PAMPRE experiment).

The Argon-silane dust is composed by grains with a $(90 \pm 20) \mathrm{nm}$ size range (Fig. 1 a), with a core obtained by coalescence and a surface deposition of $\mathrm{SiH}_{\mathrm{x}}$ species on individual grains [7]. The colour is reddish.

The two Nitrogen-methane samples (tholins) have brown colours. The dust produced with $2 \%$ methane is darker than the dust produced with $10 \%$ methane. The size distribution of the $2 \%$ sample is narrower than of the $10 \%$ sample, $(720$ $\pm 200) \mathrm{nm}$; although some micron-sized grains are observed; the grains are individual. The size distribution of the $10 \%$ sample is larger, $(650 \pm 400) \mathrm{nm}$, a large number of sintered grains is found in micron-sized aggregates (Fig. 1c).

The particles in the field of view of the PROGRA ${ }^{2}$ cameras are loose agglomerates $(50-100 \mu \mathrm{m})$ of the constituent grains. The phase curves depend mainly on the size on the constituent grains, on the refractive index of the materials and on the wavelength $[4,5]$.

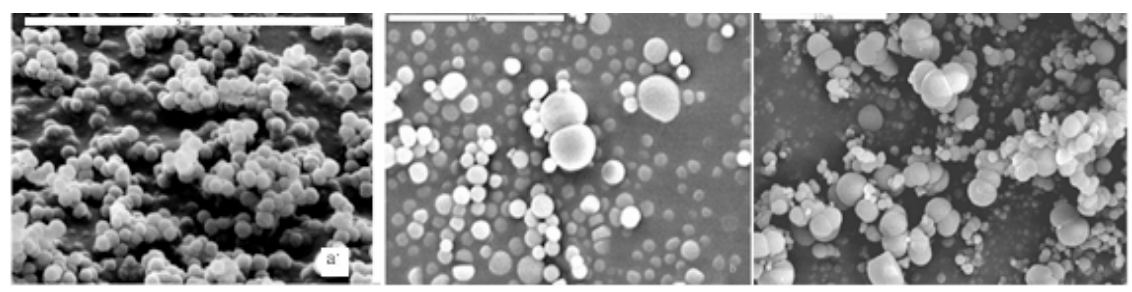

FIGURE 1. SEM images. a. Dust grains from Argon-silane plasma (scale $5 \mu \mathrm{m}$ )

b. Dust particles from Nitrogen-methane (2\%) plasma (scale $10 \mu \mathrm{m})$

c. Dust particles from Nitrogen-methane $(10 \%)$ plasma (scale $10 \mu \mathrm{m})$ 


\section{RESULTS AND DISCUSSION}

Differences are observed between the phase curves of the studied samples: the phase angle at maximum (influence of the real part of the refractive index) and the inversion angles are different for the silane dust and the tholins (Fig. 2 and 3). The three polarimetric phase curves present a negative polarization in the back scattering region up to a phase of about $20^{\circ}$ for the silane dust and $50^{\circ}$ for the tholins. The positive branch is bell shaped. By comparison to previous studies some characteristics of the particles can be deduced from the phase curves.

For the silane sample, the negative branch could be the result of the coating by the SiHx radicals, such results were obtained by numerical simulations for aggregates of silicate coated spheres [8]. To interpret the deeper negative branch for the $2 \%$ tholin as compared to those obtained for the $10 \%$ one, more investigations are necessary (e.g. refractive index determination).

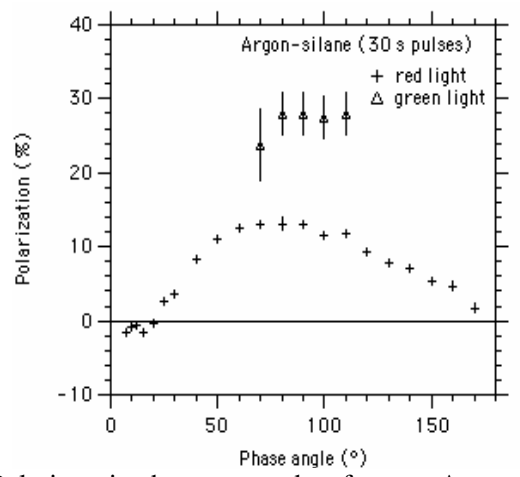

FIGURE 2. Polarimetric phase curve, dust from an Argon-silane RF plasma
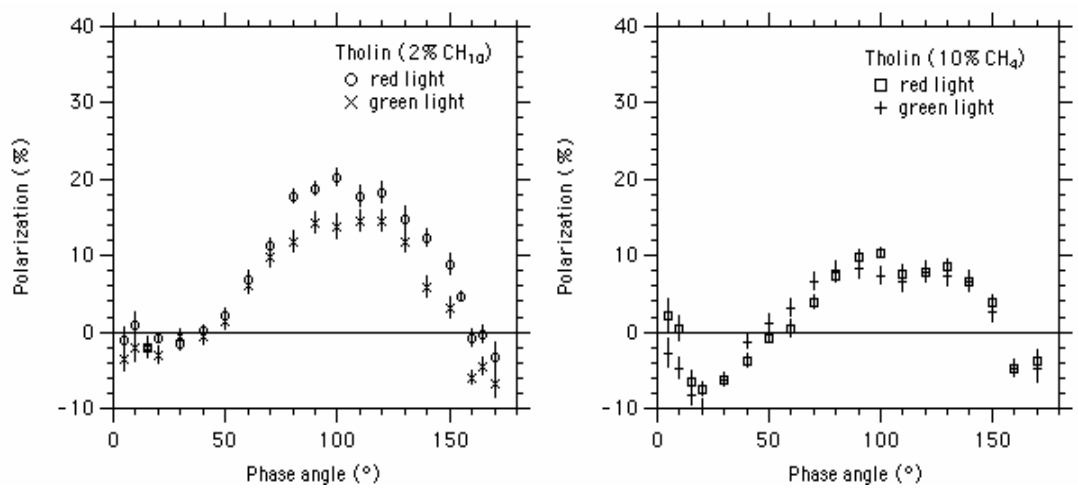

FIGURE 3: Polarimetric phase curves, dust from a Nitrogen-methane RF plasmas. 
The fact that the polarization at maximum is higher in green than in red is likely to be the result of larger absorption in green than in red (reddish colour of the sample). The lower polarization at maximum for the $10 \%$ sample reflects the presence of micron-sized single or aggregated grains and a lower absorption as compared to the $2 \%$ sample. For light scattering, a key parameter is the size parameter (ratio of the perimeter to the wavelength). It could be the reason why the maximum polarization is higher in red than in green for the $2 \%$ sample (which presents a relative narrow size distribution) and why it is lower for the 10 $\%$ sample (lower number of micron-sized particles).

\section{CONCLUSION}

Significant differences are noted between the retrieved phase curves, and the wavelength dependence thereof, for the three dust samples produced by RF plasmas Up to now, the size distribution is too large, the refractive index is not known and it is difficult to go further in the interpretations. Mono-disperse grains are needed to build a database for RF produced plasmas, and then it will be possible to study the particles growth in the reactors.

\section{ACKNOWLEDGEMENTS}

This work was supported by CNES.

\section{REFERENCES}

1. J.B. Renard, E. Hadamcik, T. Lemaire, J.C. Worms and A.C. Levasseur-Regourd, Adv. Space Res. 31, 2511-2518 (2003)

2. A.C. Levasseur-Regourd, Adv. Space Res. 31/12, 2599-2606 (2003)

3. J.B. Renard, J.C. Worms, T. Lemaire, E. Hadamcik and N. Huret, Appl; Opt. 41, 609-618 (2002)

4. E. Hadamcik, J.B. Reanrd, A.C. Levasseur-Regourd, J.C. Worms, J. Quant..Spectros.Radiat.. Transfer 79-80, 679-693 (2003)

5. E. Hadamcik, J.B. Renard,A.C. Levasseur-Regourd, J.C. Worms and M. Masson, Icarus, 155, 497-508 (2002)

6. C. Szopa, G. Cernogora, J.J. Correia, L. Boufendi, A. Jolly, this volume (2005)

7. L. Boufendi and A. Bouchoule, Plasma Sources Sci. Technol. 3, 262-267 (1994).

8. J. Lasue and A.C. Levasseur-Regourd, in: Proceedings of $8^{\text {th }}$ conference on electromagnetic and light scattering by nonspherical particles: theory, measurements and applications, edited by $\mathrm{F}$. Moreno, J.J. Lopez-Moreno, O. Munoz, Grenada, Institute de Astrophysica di Andalucia and De partment di Fisica Aplicada, 2005, pp. 191-194. 